OPEN ACCESS

Edited by:

Yuan Shi,

Children's Hospital of Chongqing Medical University, China

Reviewed by:

Branka Šošić-Jurjević,

University of Belgrade, Serbia

Patrick Diel,

German Sport University

Cologne, Germany

${ }^{*}$ Correspondence:

Kok-Yong Chin

chinkokyong@ppukm.ukm.edu.my

Specialty section: This article was submitted to

Neonatology

a section of the journal

Frontiers in Pediatrics

Received: 10 April 2020

Accepted: 03 August 2020

Published: 11 September 2020

Citation:

Chin K-Y and Pang K-L (2020) Skeletal Effects of Early-Life Exposure

to Soy Isoflavones - A Review of Evidence From Rodent Models.

Front. Pediatr. 8:563.

doi: 10.3389/fped.2020.00563

\section{Skeletal Effects of Early-Life Exposure to Soy Isoflavones-A Review of Evidence From Rodent Models}

\author{
Kok-Yong Chin ${ }^{1,2 *}$ and Kok-Lun Pang ${ }^{1}$ \\ ${ }^{1}$ Department of Pharmacology, Faculty of Medicine, Universiti Kebangsaan Malaysia, Kuala Lumpur, Malaysia, ${ }^{2}$ State Key \\ Laboratory of Oncogenes and Related Genes, Department of Urology, Renji-Med X Clinical Stem Cell Research Center, \\ School of Medicine, Ren Ji Hospital, Shanghai Jiao Tong University, Shanghai, China
}

Isoflavones are dietary phytoestrogens commonly found in soy-based products. The widespread presence of isoflavones in soy infant formula and breast milk may have long-lasting effects on the development of sex hormone-sensitive organs like the skeleton. Animal early-life programming models are suitable for testing the skeletal effects of pre- and neonatal exposure of soy isoflavones. This review aims to collate the impacts of early-life exposure of soy isoflavones as evidenced in animal models. The isoflavones previously studied include daidzein, genistein, or a combination of both. They were administered to rodent pups during the first few days postnatal, but prolonged exposure had also been studied. The skeletal effects were observed when the animals reached sexual maturity or after castration to induce bone loss. In general, neonatal exposure to soy isoflavones exerted beneficial effects on the skeletal system of female rodents, but the effects on male rodents seem to depend on the time of exposure and require further examinations. It might also protect the animals against bone loss due to ovariectomy at adulthood but not upon orchidectomy. The potential benefits of isoflavones on the skeletal system should be interpreted together with its non-skeletal effects in the assessment of its safety and impacts.

Keywords: bone, daidzein (CID 5281708), genistein (CID 5280961), neonates, life cycle, imprinting, perinatal, diethylstilbestrol (DES)

\section{INTRODUCTION}

Developmental programming or imprinting refers to the phenomenon whereby changes in the early development of an organism can exert long-lasting impacts that manifest during adulthood (1). Antenatal glucocorticoid use among pregnant women at risk of preterm delivery to assist the maturation of lungs of newborns is an example (2). Recent studies suggest the development of metabolic and cardiovascular abnormalities during adulthood in the offspring of mothers receiving glucocorticoids (3). This phenomenon has been replicated in primate models recently, whereby antenatal glucocorticoid exposure led to obesity in adult male baboons (4). The prevailing theory about the mechanism of developmental programming is epigenetic regulation by DNA methylation and histone modification induced by various factors (5).

The skeletal system is responsive to hormones and hormone-like substances. Prenatal and neonatal exposure of the skeletal system to hormonal stimuli might alter the trajectory of skeletal 
development. A single dose of estrogen at the first postnatal day could increase the bone mineral density (BMD) and cortical thickness of male mice at the prepubertal stage, but the inverse happened at the stage of peak bone mass acquisition (6). Prenatal and postnatal exposure of bisphenol A, a synthetic xenoestrogen, lowered the femoral bone stiffness of female rats but not in males (7). These studies highlight that early exposure of xenoestrogens can potentially impact bone development.

Isoflavones are phytoestrogens present abundantly in soybased products (8) and are also an important source of dietary xenoestrogens to human infants. The average isoflavone content in soy infant formula ranges from 25 to $28 \mathrm{mg} / 100 \mathrm{~g}$ of powder, consisting of daidzein (DAI), genistein (GEN), and glycitein (9). Additionally, these isoflavones are also present in breast milk (10). Setchell et al. reported that circulating isoflavones of infants were 13,000-22,000 times higher than the estradiol level, and the exposure level was 6-11 times higher than the dose in adults with regular soy food intake (11). The American Academy of Pediatrics Committee on Nutrition only recommends soy formula to infants with inherited galactosemia, lactose intolerance, or from vegan families (12). Soy formulation is not recommended to infants with cow milk protein allergy because some of them also experience allergy to soy protein (12). A study in the United States showed that $11.6 \%$ of the infants $\leq 12$ months consuming formula were being fed with soybased products (13). The prevalent use of soy infant formula that may imply the reason to consume these products is based on preference rather than medical reasons. Other committees around the world take a stricter stand against the use of soy infant formula over concerns of the biological activities of phytoestrogens (14).

The skeletal effects of soy isoflavones take decades to develop, and the planning of epidemiological studies or interventional trials on this topic is difficult. Animal models of prenatal and neonatal programming enable us to have a glimpse of the potential effects of soy isoflavones on skeletal developments. Animals like rodents have a relatively short life cycle, so developmental changes can be examined within a shorter time. The purpose of this review is to examine the skeletal effects of early-life exposure to soy isoflavones in animal models of prenatal and neonatal programming.

\section{ANIMAL MODELS}

In toxicity testing, the neonatal life stage refers to the period from birth to 3 weeks of age (15), but the definition is debatable because newborn rodents are very immature due to the short gestation period, and some researchers suggest they better resemble human preterm infants (16). A similar definition has been used for rats (17). Thus, this review will focus on rodent models supplemented with soy isoflavones within this period. We noted that most neonatal and prenatal studies are the collective work of one research group, so the reader should take note of potential publication bias.

Most studies examining neonatal exposure of soy isoflavones on the skeletal system used mice as the model organism. The soy isoflavones studied included DAI, GEN, or a combination of both. Since the binding affinity of different types of isoflavones on biological targets, like estrogen receptors (18), are different, this could contribute to the variation of the results among the studies. Notably, a study reported that skeletal effects of a combination of GEN and DAI were less prominent compared to individual isoflavones (19), suggesting that the less active isoflavone could attenuate the effects of the more potent isoflavone.

The soy isoflavones were administered subcutaneously during the first few postnatal days, and the skeletal outcomes were assessed when the mice reached maturity (4 months of age), with diethylstilbestrol (DES) as the positive control. The dose and type of isoflavone used in each study were different [GEN, $4 \mu \mathrm{g} /$ day $\mathrm{sc}$ or $5 \mathrm{mg} / \mathrm{kg}$ body weight (bw)/day sc; DAI, $2 \mathrm{mg} / \mathrm{kg}$ bw/day sc; GEN + DAI, $7 \mathrm{mg} / \mathrm{kg}$ bw/day sc]; thus, the skeletal effects may not be comparable between studies. Other variations of the models exist. Two studies assessed the skeletal effects of prenatal exposure of folic acid (FA) and postnatal exposure of isoflavones on mice $(20,21)$; thus, the effects of isoflavones were confounded by prenatal FA treatment.

In the prenatal and postnatal rat model $(22,23)$, soy isoflavones were administered through food, in contrast to subcutaneous for studies in mice. Soy isoflavones like DAI are known to be metabolized by gut microbiomes to equol and $\mathrm{O}$-desmethylangolensin with different biological activities compared to the parent compounds (24). However, in all studies reviewed, the bioavailability of the isoflavones and their metabolites were not measured. Along with the doses that were not readily translatable between the mouse and rat studies, these factors prevent effective comparisons between different research groups.

Another study exposed the mouse pups with isoflavones, castrated them in the fourth month, and assessed their bone health status in the eighth month (25). The castration model is a classic bone loss model due to sex hormone deficiency (26), so the mentioned study examined the antiosteoporosis effects of early exposure to isoflavones.

The composition of the control diet is essential to ensure a fair comparison between the isoflavone-supplemented and control groups. Long-term supplementation of different diet regimens with and without soy isoflavones or protein can modify body composition and metabolic profile of the animals (27). Most studies indicated the use of soy-free diet. Modified AIN93G diet without isoflavones is the most common diet used $(19,23,28)$, while other studies indicated the use of diet without DAI (23) or isoflavones (22), or amino acid-based diet without isoflavones $(20,21)$. The difference in the composition of these diets could cause variation in the results of the studies reviewed.

The design of the studies is shown in Table $\mathbf{1}$ for comparison.

\section{NEONATAL EXPOSURE}

\section{Effects on Bone Mass}

Bone mineral density (BMD) assessment through dual-energy Xray absorptiometry in animals allows non-invasive longitudinal changes in bone mass (29). Neonatal exposure to GEN increased the femoral BMD of mice at sexual maturity. Additionally, it 
TABLE 1 | Skeletal effects of prenatal and/or neonatal exposure of soy isoflavones derived from animal studies.

\begin{tabular}{|c|c|c|c|c|c|}
\hline Study & Study design & Bone mineral density & Bone microstructure & Bone strength & $\begin{array}{l}\text { Bone remodeling and } \\
\text { biochemical markers }\end{array}$ \\
\hline \multirow[t]{2}{*}{$\begin{array}{l}\text { Peikarz and Ward } \\
\text { (28) }\end{array}$} & $\begin{array}{l}\text { CD-1 mouse pups were } \\
\text { exposed to corn oil, GEN (4 } \\
\mu \mathrm{g} / \text { day sc), or DES ( } 2 \mu \mathrm{g} / \text { day } \\
\text { sc) for the first } 5 \text { days of life. } \\
\text { Outcomes measured at } 4 \\
\text { months of age. } \\
\text { Control diet: AIN93G diet } \\
\text { without ISO }\end{array}$ & $\begin{array}{l}\text { Male } \\
\text { Femoral BMD: GEN = } \\
\text { corn oil < DES } \\
\text { Lumbar BMD: GEN > } \\
\text { DES = corn oil }\end{array}$ & NA & $\begin{array}{l}\text { Male } \\
\text { Femoral peak load: GEN = } \\
\text { corn oil < DES } \\
\text { Lumbar peak load: GEN > } \\
\text { DES = corn oil }\end{array}$ & $\begin{array}{l}\text { Male } \\
\text { Serum osteocalcin: GEN } \\
=\text { DES < corn oil Serum } \\
\text { CTX-1: NS }\end{array}$ \\
\hline & & $\begin{array}{l}\text { Female } \\
\text { Femoral BMD: GEN }= \\
\text { DES > corn oil } \\
\text { Lumbar BMD: GEN = } \\
\text { DES > corn oil }\end{array}$ & NA & $\begin{array}{l}\text { Female } \\
\text { Femoral Peak load: NS } \\
\text { Lumbar peak load: GEN = } \\
\text { DES > corn oil }\end{array}$ & $\begin{array}{l}\text { Female } \\
\text { Serum osteocalcin \& } \\
\text { CTX-1 NS }\end{array}$ \\
\hline \multirow[t]{2}{*}{$\begin{array}{l}\text { Kaludjerovic and } \\
\text { Ward (19) }\end{array}$} & $\begin{array}{l}\text { CD-1 mouse pups were } \\
\text { exposed to corn oil, DAl (2 } \\
\mathrm{mg} / \mathrm{kg} \text { bw/day sc), GEN (5 } \\
\mathrm{mg} / \mathrm{kg} \text { bw/day sc), DAl + } \\
\text { GEN (ISO, } 7 \mathrm{mg} / \mathrm{kg} \text { bw/day } \\
\mathrm{sc} \text { ), or DES ( } 2 \mathrm{mg} / \mathrm{kg} \text { bw/day } \\
\text { sc) for the first } 5 \text { days of life. } \\
\text { Outcomes measured at } 4 \\
\text { months of age. } \\
\text { Control diet: AIN93G diet } \\
\text { without } \\
\text { estrogenic compounds. }\end{array}$ & $\begin{array}{l}\text { Male } \\
\text { Lumbar BMD: DES = all } \\
\text { isoflavones group > corn } \\
\text { oil } \\
\text { Femoral midpoint BMD: } \\
\text { DAI > GEN = ISO = } \\
\text { DES = corn oil }\end{array}$ & NA & $\begin{array}{l}\text { Male } \\
\text { Lumbar peak load: NS } \\
\text { Femoral midpoint yield: NS } \\
\text { Femoral midpoint peak load: } \\
\text { DES < DAl = ISO, DES = } \\
\text { corn oil = GEN } \\
\text { Femoral midpoint stiffness: NS } \\
\text { Femoral neck yield: DAl > } \\
\text { DES, ISO > DES, corn oil = } \\
\text { DES = GEN } \\
\text { Femoral neck peak load: DAl } \\
\text { > corn oil = GEN = ISO } \geq \\
\text { DES } \\
\text { Femoral neck stiffness: NS }\end{array}$ & NA \\
\hline & & $\begin{array}{l}\text { Female } \\
\text { Lumbar BMD: DES > all } \\
\text { isoflavones group }=\text { corn } \\
\text { oil } \\
\text { Femoral midpoint BMD: } \\
\text { DAl > GEN = ISO = } \\
\text { DES = CON }\end{array}$ & 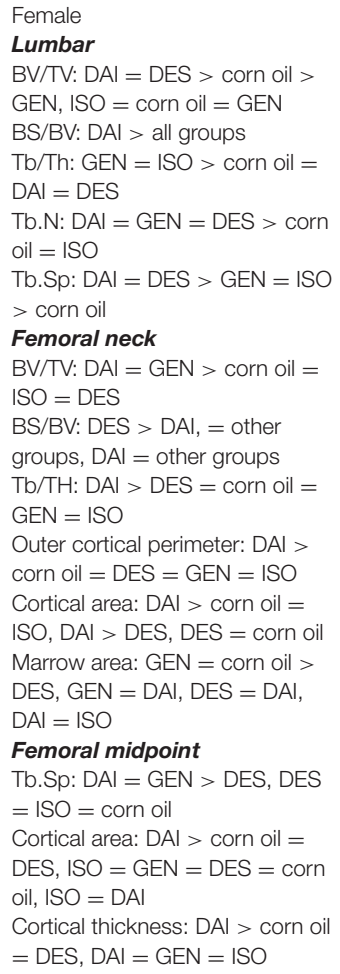 & $\begin{array}{l}\text { Female } \\
\text { Lumbar peak load: DAI = DES } \\
>\text { ISO = corn oil Femoral } \\
\text { midpoint yield: DES > all } \\
\text { isoflavones = corn oil Femoral } \\
\text { midpoint peak load: corn oil < } \\
\text { DES > GEN = ISO, } \\
\text { isoflavones > corn oil Femoral } \\
\text { midpoint stiffness: corn oil < } \\
\text { all isoflavones, DES = DAI > } \\
\text { GEN = ISO Femoral neck } \\
\text { yield, peak load, stiffness: NS }\end{array}$ & NA \\
\hline $\begin{array}{l}\text { Kaludjerovic and } \\
\text { Ward (25) }\end{array}$ & $\begin{array}{l}\text { CD-1 mouse pulps were } \\
\text { exposed to corn oil, DAl + } \\
\text { GEN (ISO, } 7 \mathrm{mg} / \mathrm{bw} / \mathrm{day} \mathrm{sc}) \text {, } \\
\text { or DES ( } 2 \mathrm{mg} / \mathrm{bw} / \text { day sc) for } \\
\text { the first } 5 \text { days of life. } \\
\text { Castration was performed at } \\
\text { 4th month. Outcomes } \\
\text { measured at } 8 \text { th month of life. } \\
\text { Control diet: AIN93G diet }\end{array}$ & $\begin{array}{l}\text { Male } \\
\text { Lumbar BMD: NS Whole } \\
\text { femur BMD: NS }\end{array}$ & NA & $\begin{array}{l}\text { Male } \\
\text { Lumbar peak load: NS } \\
\text { Femoral midpoint peak load, } \\
\text { yield, stiffness: NS } \\
\text { Femoral neck peak load: ISO } \\
\text { > DES, DES = corn oil } \\
\text { Femoral neck yield, stiffness: } \\
\text { NS }\end{array}$ & NA \\
\hline
\end{tabular}


TABLE 1 | Continued

\begin{tabular}{|c|c|c|c|c|c|}
\hline Study & Study design & Bone mineral density & Bone microstructure & Bone strength & $\begin{array}{l}\text { Bone remodeling and } \\
\text { biochemical markers }\end{array}$ \\
\hline & & $\begin{array}{l}\text { Female } \\
\text { Lumbar BMD, BMC: ISO } \\
\text { > corn oil = DES } \\
\text { Whole femur BMD: ISO } \\
\text { > corn oil, = DES, corn } \\
\text { oil = DES }\end{array}$ & $\begin{array}{l}\text { Female } \\
\text { Lumbar } \\
\text { BV/TV: NS Tb/Th: DES = ISO > } \\
\text { corn oil Tb.N: DES > corn oil, } \\
\text { ISO = DES = corn oil Tb.Sp: NS } \\
\text { Femoral neck: } \\
\text { All NS }\end{array}$ & $\begin{array}{l}\text { Female } \\
\text { Lumbar peak load: DAI + } \\
\text { GEN > corn oil = DES } \\
\text { Femoral midpoint peak load: } \\
\text { ISO > corn oil = DES Femoral } \\
\text { midpoint yield, stiffness: NS } \\
\text { Femoral neck peak load, yield, } \\
\text { stiffness: NS }\end{array}$ & NA \\
\hline Hertrampf et al. (22) & $\begin{array}{l}\text { Sprague-Dawley female rats } \\
\text { Dams fed with diet without } \\
\text { isoflavones (IDD), mixed } \\
\text { isoflavone diet (IRD: GEN } \\
240 \mu \mathrm{g} / \mathrm{g}+\mathrm{DAl} 232 \mu \mathrm{g} / \mathrm{g}) \text {, or } \\
\text { GEN }(700 \mu \mathrm{g} / \mathrm{g} \text { diet). Pups fed } \\
\text { with the same diet as dams } \\
\text { for } 80 \text { days postnatal }{ }^{*}\end{array}$ & $\begin{array}{l}\text { Tibial BMD at Day 21: } \\
\text { GEN }=I R D>I D D\end{array}$ & NA & NA & NA \\
\hline $\begin{array}{l}\text { Kaludjerovic and } \\
\text { Ward (20) }\end{array}$ & $\begin{array}{l}\text { CD-1 mouse dams fed with } \\
\text { low (0 mg/kg bw/day), } \\
\text { adequate ( } 2 \mathrm{mg} / \mathrm{kg} \text { bw/day) } \\
\text { and supplementary ( } 8 \mathrm{mg} / \mathrm{kg} \\
\text { bw/day) FA. Pups fed with } \\
\text { either corn oil or DAl + GEN } \\
\text { (ISO, } 7 \mathrm{mg} / \mathrm{kg} \text { bw/day, sc) } \\
\text { from day } 1-10 \text { after birth. } \\
\text { Outcomes measured at } 4 \\
\text { months of age. Only male } \\
\text { pulps are studied. } \\
\text { Control diet: amino } \\
\text { acid-based diet without ISO }\end{array}$ & $\begin{array}{l}\text { Male } \\
\text { Lumbar BMD: Overall } \\
\text { ISO > no ISO } \\
\text { Whole femur BMD: ISO } \\
\text { + adequate FA group > } \\
\text { FA only }\end{array}$ & NA & $\begin{array}{l}\text { Male } \\
\text { Lumbar peak load: Overall ISO } \\
\text { > no ISO } \\
\text { Whole and midpoint femur } \\
\text { peak load: ISO + adequate FA } \\
\text { group > FA only }\end{array}$ & $\begin{array}{l}\text { Male } \\
\text { Serum biomarkers OPG } \\
\text { and OPG/RANKL ratio: } \\
\text { ISO + supplementary FA } \\
\text { group > FA only }\end{array}$ \\
\hline $\begin{array}{l}\text { Kaludjerovic and } \\
\text { Ward (21) }\end{array}$ & $\begin{array}{l}\text { CD-1 mouse dams fed with } \\
\text { low (0 mg/kg bw/day), } \\
\text { adequate ( } 2 \mathrm{mg} / \mathrm{kg} \text { bw/day), } \\
\text { and supplementary ( } 8 \mathrm{mg} / \mathrm{kg} \\
\text { bw/day) FA. Pups fed with } \\
\text { either corn oil or DAl }+\mathrm{GEN} \\
\text { (ISO, } 7 \mathrm{mg} / \mathrm{kg} \text { bw/day, sc) } \\
\text { from days } 1-10 \text { after birth. } \\
\text { Outcomes measured at } 4 \\
\text { months of age. Only female } \\
\text { pulps are studied. } \\
\text { Control diet: amino acid based } \\
\text { diet free from ISO }\end{array}$ & $\begin{array}{l}\text { Female } \\
\text { Femur and lumbar BMD: } \\
\text { adequate FA + ISO } \\
\text { group > FA only }\end{array}$ & $\begin{array}{l}\text { Female } \\
\text { Lumbar BV/TV, Tb.N: Overall ISO } \\
\text { > no ISO } \\
\text { Lumbar Tb.Sp: Overall ISO < no } \\
\text { ISO } \\
\text { Femur Tb.Th, Tb.N: Adequate FA } \\
+ \text { ISO > FA only }\end{array}$ & $\begin{array}{l}\text { Female } \\
\text { Lumbar peak load: NS Femur } \\
\text { midpoint peak load: ISO + } \\
\text { adequate FA group > FA only }\end{array}$ & $\begin{array}{l}\text { Female } \\
\text { OPG, OPG/RANKL, } \\
\text { IGF-1: Adequate FA + } \\
\text { ISO > FA only Dnmt3a } \\
\text { mRNA: } \\
\text { Adequate FA + ISO < FA } \\
\text { only; Supplemental FA + } \\
\text { ISO > FA only } \\
\text { NPY mRNA: Adequate } \\
\text { FA + ISO < FA only }\end{array}$ \\
\hline \multirow[t]{2}{*}{ Tousen et al. (23) } & $\begin{array}{l}\text { Control: Sprague-Dawley } \\
\text { dams and offspring fed on } \\
\text { DAl-free diet. } \\
\text { D1: Sprague-Dawley dams } \\
\text { and offspring fed with DAl (0.5 } \\
\text { g/kg diet) till postnatal } \\
\text { day } 13^{\star *}\end{array}$ & $\begin{array}{l}\text { Male } \\
\text { Whole femur } \boldsymbol{B M D} \\
\text { Day 22: D1 = control } \\
\text { Day 35: D1 < control } \\
\text { Day 77: D1 < control }\end{array}$ & NA & NA & $\begin{array}{l}\text { Male } \\
\text { Serum osteocalcin } \\
\text { Day 22: D1 < control } \\
\text { Day 35: D1 = control } \\
\text { Day 77: D1 = control }\end{array}$ \\
\hline & & $\begin{array}{l}\text { Female } \\
\text { Whole femur BMD Day } \\
\text { 22: D1 = control } \\
\text { Day 35: D1 < control } \\
\text { Day 77: D1 = control }\end{array}$ & NA & NA & $\begin{array}{l}\text { Female } \\
\text { Serum osteocalcin } \\
\text { Day 22: D1 = control } \\
\text { Day 35: D1 < control } \\
\text { Day } 77: \text { D1 = control }\end{array}$ \\
\hline
\end{tabular}

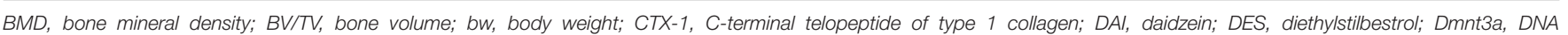

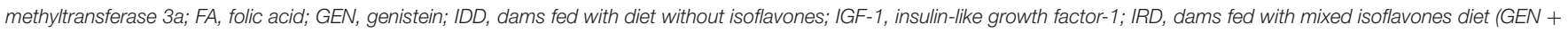

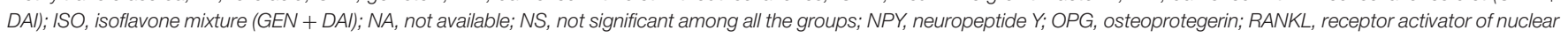
factor kappa-B ligand; Tb.N, trabecular number; Tb.Th, trabecular thickness; Tb.Sp, trabecular separation; sc, subcutaneous.

*Only data till day 21 is included in this table. ${ }^{* *}$ There was another group fed till postnatal day 77.

also increased the lumbar BMD of female mice (28). The effects of GEN was greater than DES in males but on par with DES in female mice (28). In another study, DAI was more potent than GEN, DAI + GEN, and DES in increasing the femoral midpoint BMD of mice (19). However, DES exerted greater effects on female, while all treatments exerted similar effects on male lumbar BMD (19). In prenatal FA and postnatal isoflavone $(\mathrm{DAI}+\mathrm{GEN})$ models, femoral and lumbar BMD increased significantly in male mice exposed to adequate FA $(2 \mathrm{mg} / \mathrm{kg}$ bw/days) and postnatal isoflavone compared to other treatment 
groups (20). Similar treatment resulted in higher lumbar and femoral BMD of the female mice (21). Neonatal isoflavone exposure (DAI + GEN) also prevented deterioration of lumbar and femoral BMD due to castration in female rats but not in male rats (25).

Overall, neonatal exposure to isoflavones increased BMD of the mice at sexual maturation, and the effects were slightly better in male mice. However, it did not protect male mice against bone loss due to sex hormone deficiency. These observations suggest that both androgenic and estrogenic stimulation are essential in the development of the skeleton in males $(30,31)$. On the other hand, the adverse effects of androgen deprivation on bone are tremendous and cannot be displaced by earlier BMD gain caused by soy isoflavones.

BMD cannot differentiate between the trabecular and cortical compartment, and it has a low resolution (8). Microcomputed tomography assessment, which is discussed below, provides a more complete picture of the microstructure in each bone compartment.

\section{Effects on Bone Microarchitecture}

Skeletal microarchitecture is a major determinant of bone strength, which can be studied through microcomputed tomography (32). Neonatal exposure of DAI significantly improved the trabecular microstructure indices of the lumbar spine and femoral neck, and the trabecular separation of the femoral midpoint in female mice (19). The effects of GEN were superior to those of DAI on lumbar trabecular thickness (19). Similarly, neonatal isoflavone exposure independently increased lumbar trabecular microstructure in female offspring from dams supplemented with FA during gestation (21).

On cortical bone indices, DAI increased the cortical area of the femoral neck and midpoint (19). DAI, GEN, and DAI + GEN also improved cortical thickness of the midpoint but not at the femoral neck (19).

Overall, data on neonatal exposure of isoflavones on bone microarchitecture is limited. The available study showed that improvements were site specific. The lumbar spine and femoral neck are trabecular rich; therefore, the improvement in trabecular indices is better. The femoral midshaft is cortical rich; hence, cortical improvement is more apparent. The variations in bone composition could significantly influence the effects of isoflavones on different bone regions, which dictates bone strength.

\section{Effects on Bone Strength}

The ultimate measure of bone health is skeletal strength, which predicts fracture risk. The usual indices include ultimate/peak load, which refers to bone strength under certain specific loading conditions, and stiffness, which refers to the resistance of the bone against deformation (33). Neonatal GEN significantly increased the lumbar, but not the femoral, peak load of adult male mice compared to DES, and the normal control (28). The effects of neonatal GEN and DES exposure on lumbar peak load were similar in adult female mice, whereby an improvement over normal control was observed (28). Both compounds did not alter the femoral peak load in adult female mice (28). Since the lumbar spine is rich in trabecular bone, the improvement in strength could be a result of enhanced trabecular bone structure.

On the other hand, neonatal DAI exposure increased the femoral neck and midpoint peak load in adult male mice but not in female mice (19). The effects of DAI were greater than those of DES in male mice, while the effects of GEN or DAI + GEN were intermediary (19). Neonatal isoflavone exposure only retained the peak load of the femoral neck in male mice and the peak load of the femoral midpoint in female mice after castration (25). Adequate prenatal FA and postnatal isoflavone exposure increased the lumbar and femoral peak loads in male mice (20). Contradictory to BMD results, the femoral midpoint, but not the lumbar peak load, was higher in female mice treated with adequate prenatal FA + postnatal isoflavone (21). The beneficial effects on cortical-rich regions in these studies due to DAI or isoflavone mixture with DAI correspond to the results of skeletal microstructure, whereby DAI increased cortical thickness. It also warrants further investigation on whether the skeletal action of DAI is selective on cortical bones.

Overall, neonatal isoflavone exposure generally improves the bone strength of mice, but the skeletal sites vary due to the type of isoflavones present.

\section{Effects on Bone Remodeling}

Bone remodeling refers to the tightly regulated process of bone resorption by osteoclasts and formation by osteoblasts (34). The bone remodeling process can be inferred by circulating markers of bone resorption and formation, which are the products of bone cell activities (35). Neonatal GEN exposure did not change the serum C-terminal telopeptide of type I collagen (CTX-1; bone resorption markers) and osteocalcin level (bone formation markers) in mice (28). On the other hand, adequate prenatal FA plus postnatal isoflavone increased osteoprotegerin (OPG) and OPG/receptor activator of nuclear factor kappa- $\beta$ ligand (RANKL) ratio in male mice (20) and female mice (21). Since OPG prevents the action of RANKL in stimulating osteoclast differentiation, this observation indicates the suppression of bone resorption (36). Additionally, the serum level of insulin-like factor-1, a bone anabolic hormone, was increased in female mice (21).

Overall, neonatal isoflavone exposure might suppress the formation of osteoclasts, but this observation was not reflected in the bone resorption markers. Perhaps this change is transient and has normalized upon adulthood.

\section{MODELS AND PRENATAL AND NEONATAL EXPOSURE}

Other studies reported a longer period of isoflavone exposure involving the prenatal and neonatal periods. We limit our discussion to studies with postnatal exposure within the limit of the neonatal period of life. Tousen et al. (23) reported on the skeletal effects of rat dams fed with DAI from gestation till postnatal day 13 and their offspring fed with control diet until weaning. The whole BMD of the male and female offspring was 


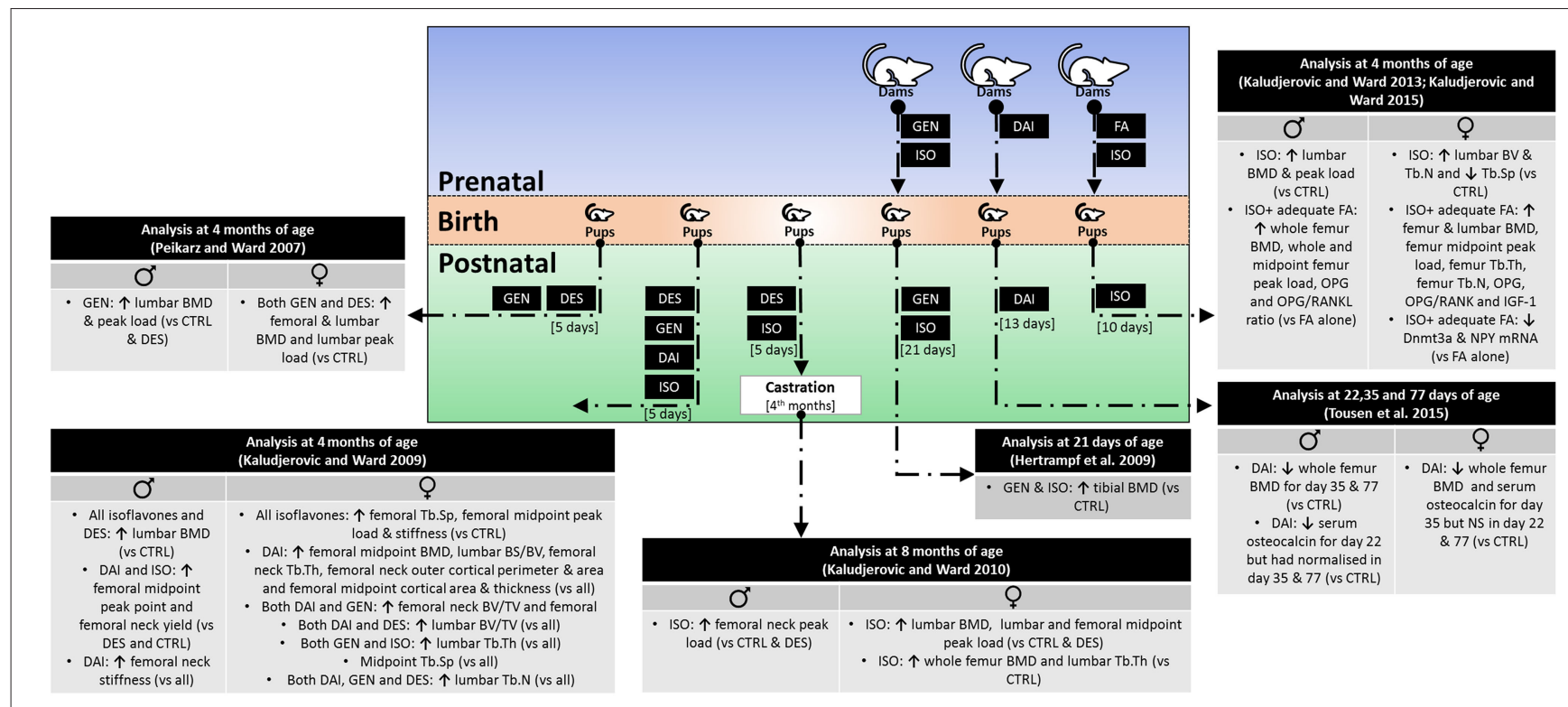

FIGURE 1 | Skeletal effects of early life exposure to soy isoflavones. BMD, bone mineral density; BV/TV, bone volume over total volume; CTRL, control; DAl, daidzein; DES, diethylstilbestrol; Dnmt3a, DNA methyltransferase 3a; FA, folic acid; GEN, genistein; IGF-1, insulin-like growth factor-1; ISO, isoflavone mixture (DAI + GEN); NPY, neuropeptide Y; OPG, osteoprotegerin; RANKL, receptor activator of nuclear factor kappa-B ligand; Tb.N, trabecular number; Tb.Th, trabecular thickness;

Tb.Sp, trabecular separation.

significantly lower at the prepubertal stage (day 35) compared to the control rats (23). Upon sexual maturation (day 77), the $\mathrm{BMD}$ of the male remained lower compared to that of the normal control, but the BMD of the female returned to control values (23). The serum osteocalcin level of the exposed rats was lower compared to that of the control rats at the prepubertal stage, but the level returned to control values upon sexual maturity (23). Another study reported a lower tibial BMD in female offspring of rat dams exposed to GEN or isoflavones during gestation and lactation period (postnatal 21 days) (22). These effects persisted when the rats reached adulthood, but it should be noted that the offspring were fed with the same diet as the dams' lifelong (22).

Overall, in contrast to neonatal exposure, prenatal plus postnatal exposure of isoflavones exerted negative effects to the bone. This observation might be related to the critical period of intrauterine exposure. It was reported that soy isoflavones could regulate the epigenetic process of embryonic stem cells (37). Whether these changes are beneficial or harmful to the development of the skeletal system remains a question.

Current findings from animal experiments are summarized in Figure 1.

Prepubertal exposure of soy isoflavones also influences skeletal health at adulthood. Zhang et al. (38) showed that female rats fed with soy protein isolates for 14 days from postnatal day 20, had higher bone formation markers (alkaline phosphatase, ALP, and osteocalcin), bone resorption markers (RatLap), and sclerostin level (a negative regulator of bone formation) compared to the control. Chen et al. (39) compared the rats fed with casein or soy protein isolate-based diet starting from the postnatal day 24 till postnatal day 55 and subsequently switched to standard diet or continue with soy protein isolates till 6 months old. Some of the rats were castrated at the age of 6 months and sacrificed 1-3 weeks later. They reported that the total $\mathrm{BMC}$ and $\mathrm{BMD}$, and trabecular and cortical BMD of the soy protein isolate group were greater than those of the casein group. After castration, rats on shortterm or long-term soy protein isolates had better bone health than those on the casein diet. Overall, prepubertal exposure of soy isoflavones exerts skeletal beneficial effects similar to those of neonatal exposure models. In contrast, prenatal and postnatal exposures of soy isoflavones exert negligible or negative effects on rats in adulthood. However, apart from the period of exposure, the dose and type of isoflavones supplemented should be considered in interpreting the results of these studies.

Hotchkiss et al. (40) compared the skeletal effects of GEN in rats supplemented continuously for 2 years or switched to the control diet after postnatal day 140. Lifelong exposure to high-dose GEN resulted in lower lumbar BMC and area, as well as higher pyridinoline (a bone resorption marker) compared to those of rats supplemented with lower doses. In female rats treated till postnatal day 140, pyridonoline was lower and ALP was higher with higher GEN dose, indicating that GEN induced higher bone formation rate in these rats. In rats treated with GEN till weaning and male rats at all life stages, no skeletal effects were observed. The data may indicate that androgenic regulation is essential for skeletal development in males and that phytoestrogenic effects of isoflavones may not be as important as in females. 


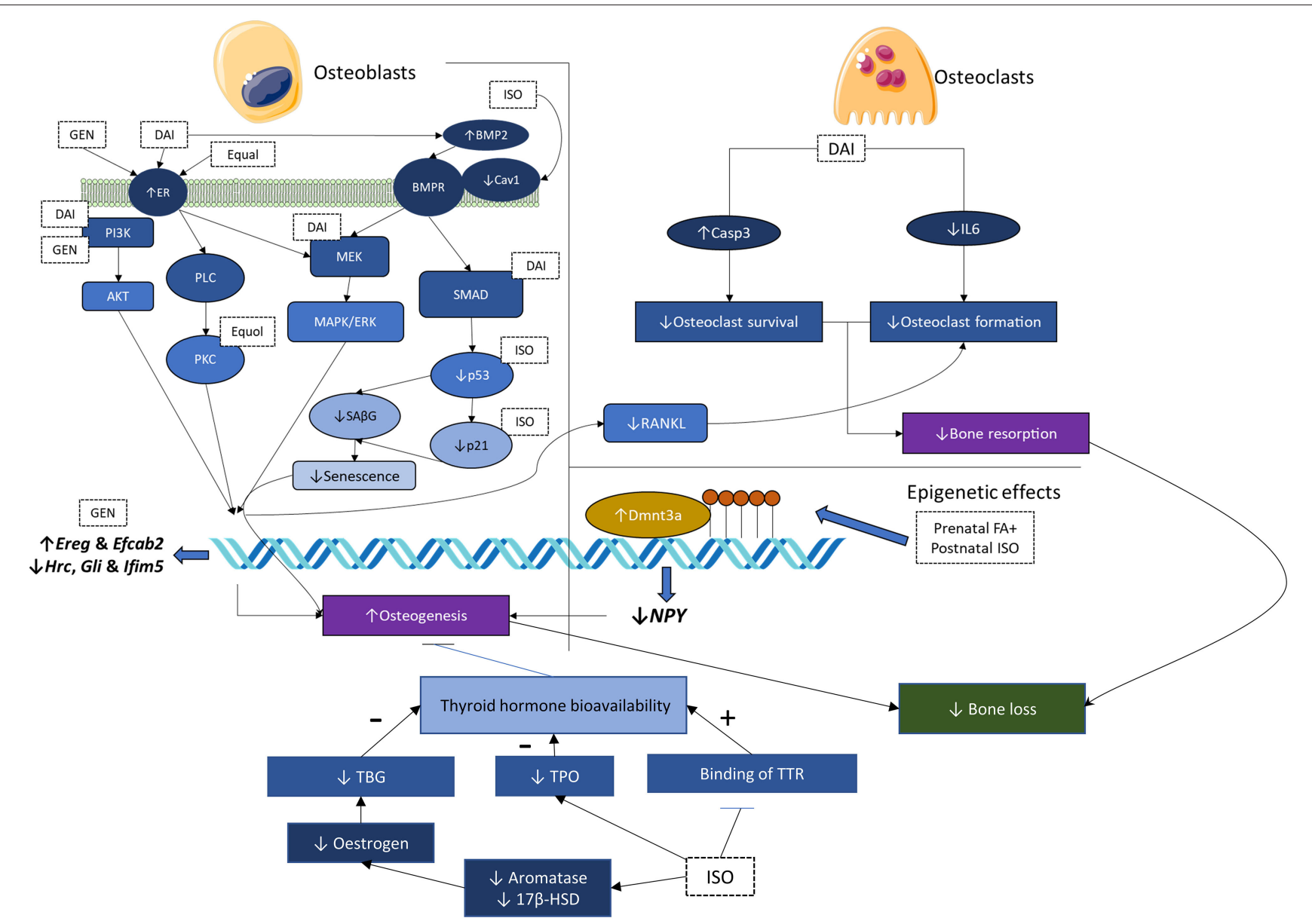

FIGURE 2 | Mechanisms of action of soy isoflavones and soy protein isolates. $17-\beta-H S D, 17-\beta$-hydroxysteroid dehydrogenase; BMP-2, bone morphogenetic protein-2; Cav1, caveolin-1; DAl, daidzein; Dnmt3a, DNA methyltransferase 3a; ER, estrogen receptor; ER- $\alpha / \beta$, estrogen receptor- $\alpha / \beta$; FA, folic acid; GEN, genistein; IL-6, interleukine-6; ISO, isoflavone mixture; MAPK, mitogen-activated protein kinase; MEK/ERK, MAPK kinase/extracellular-regulated kinase; NPY, neuropeptide Y; PI3K/Akt, phosphoinositide 3-kinase/protein kinase B; PKC, protein kinase C; PLC, phospholipase C; RANKL, receptor activator of nuclear factor kappa-B ligand; SA $\beta$ G, senescence-associated beta-galactosidase; T4, thyroxine; TBG, thyroxine-binding globulin; TH, thyroid hormone; TPO, thyroid peroxidase; TTR, transthyretin.

\section{MECHANISM OF ACTION OF ISOFLAVONES ON BONE DEVELOPMENT}

Soy isoflavones affect skeletal development through direct and indirect action on bone cells. In this section, the actions of soy isoflavones on bone cells, through DNA methylation and thyroid hormones $(\mathrm{TH})$, are discussed.

GEN exerts a positive effect on bone remodeling by reducing osteoclast and increasing osteoblast number. It lowers the osteoclast number in neonatal bone marrow cell culture through decreasing the survival of osteoclasts or attenuating their formation (41). It also increases the differentiation and migration of primary rat calvarial osteoblasts by estrogen receptor (ER) and nitric oxide synthase pathway (42). Mitogenactivated protein kinase (MAPK) and phosphoinositide 3-kinase (PI3K) transduction systems are shown to involve in the pro-osteogenesis effects of GEN (42). Surprisingly, in a coculture of osteoblasts and monocytes, GEN increased the formation of osteoclast-like cells (42), probably through stimulating factors from osteoblasts. Another study suggested the upregulation of Ereg and Efcab2, as well as downregulation of Hrc, Gli, and Ifim5 in MC3T3-E1 preosteoblastic cells (43).

Similarly, DAI promoted apoptosis of osteoclast-like cells derived from porcine bone marrow cells by caspase- 3 cleavage and upregulation of nuclear ER (44). DAI improved osteoblastic differentiation of OCT-1 cells via upregulation of bone morphogenetic protein-2 (BMP-2) and activation of the SMAD pathway (44). DAI also improved proliferation, differentiation of MG-63 osteoblasts primarily through ER $\alpha$ signaling and at least partly through MAPK kinase/extracellular regulated kinase (MEK/ERK) and the $\mathrm{PI} 3 \mathrm{~K} /$ protein kinase $\mathrm{B}$ (Akt) signaling pathway (45). Another study showed an increased expression of $\mathrm{ER} \alpha, \mathrm{ER} \beta$, and steroid receptor (SR) comprising the classic estrogen-responsive elements in MG-63 osteoblasts induced by DAI (46). It also reduced the expression of stimuli for osteoclastogenesis [RANKL and interleukin-6 (IL-6)] while increasing the expression of OPG in MG-63 osteoblasts (46). 
Equol and O-desmethylangolensin, derived from DAI metabolism, could also inhibit the formation of osteoclast-like cells from bone marrow cells from male mice (47). Equol also promoted osteoblast differentiation from primary osteoblast precursors, probably through ER and the protein kinase C- $\alpha$ (PKC- $\alpha$ ) pathway (48).

DNA methylation is an epigenetic process mediating gene expression, which plays an important role in skeletal development. It is regulated by DNA methyltransferase (Dnmt) (49). The differentiation of mesenchymal stem cells to osteoblastic or non-osteoblastic progenitors is linked to the methylation rate of critical genes encoding BMP-2 and ALP, which is responsive to the Wnt signaling pathway (50). Methylation of the gene encoding interferon regulatory factor eight facilitates osteoclastogenesis (51). Previous studies have demonstrated that the antiestrogenic effects of isoflavones could be partially attributed to its effects on the methylation of steroidogenic factor $1(49,52)$. Exposure of mouse embryonic tissues to GEN also modified the regulation level of genes (37). Since DNA methylation is the prevailing theory for neonatal imprinting effects, the effects of prenatal FA plus postnatal isoflavones on Dnmt in the bone for female mice have been explored. Postnatal isoflavone exposure decreased Dnmt3a expression in the adequate FA group but increased Dnmt3a expression in the supplemental FA group, indicating a significant interaction between FA and isoflavones (21). Gene expression analysis demonstrated that neuropeptide Y (NPY) level, a potent osteogenesis inhibitor, was suppressed in the adequate FA plus isoflavone group (21). Other epigenetic factors, like histone modifications, could also influence bone health, but the role of soy isoflavones in mediating bone health through this mechanism is less clear.

On the other hand, soy isoflavones exert their effects on the skeletal system indirectly through interference with $\mathrm{TH}$ homeostasis (53). Congenital and juvenile hypothyroidism can delay skeletal development, while thyrotoxicosis can accelerate skeletal aging and premature closure of growth plate. These phenomena have been replicated in genetically modified rodent models with altered thyroid hormone signaling (54). On the other hand, the skeletal effects of over hypo/hyperthyroidism and thyroid-stimulating hormone (TSH) are well-known $(55,56)$. Epidemiological studies showed that soy isoflavone consumption could influence TH levels. Intakes of soy isoflavones or protein are associated with high TSH, especially among women (57), which could be a result of the thyroid suppressive effect of isoflavones. In contrast, urinary isoflavone levels are found to be associated with higher serum thyroxine (T4) in women but not in men (58), in which the authors attribute the higher T4 to the suppressive effects of isoflavones on deiodination of $\mathrm{T} 4$ to T3. Mechanistically, soy isoflavones suppress the level of TH by inhibiting thyroid peroxidase (TPO) activity competitively (59) and inhibit the binding of TH to thyroid transport protein [transthyretin (TTR)] in the blood $(60,61)$. Soy isoflavones, especially GEN, are also deiodinase (Dio) inhibitors, specifically type 1 (Dio1) (62). However, Dio1 is not expressed in the bone (63). In silico analysis showed that isoflavones could bind to thyroid receptors, but this effect has not been validated in vitro (64). Isoflavones were reported to enhance transcription mediated by triiodothyronine-liganded thyroid receptor (64). Soy isoflavones also inhibit aromatase and 17- $\beta$-hydroxysteroid dehydrogenase (17- $\beta$-HSD) (65), which prevent the conversion of androgens to estrogens, thereby lowering thyroxine-binding globulin (TBG) and decreasing T4 level (66). However, TTR, instead of TBG, is the main carrier of thyroid hormones in rodent blood (67).

Soy isoflavones may also affect skeletal health through other indirect mechanisms. A multigeneration supplementation study showed that soy protein concentrates and soy isoflavones slowed down the weight gain and reduced the insulin level of the rats (27). The reduction in mechanical loading exerted by body weight and the bone anabolic insulin signaling may be harmful to the bone. Soy protein isolates also decreased the expression of caveolin-1, a membrane protein that anchors other proteins to the membrane, accompanied by activation of BMP-2/SMAD signaling in bone and osteoblasts (38). In another study, longterm soy protein isolate supplementation caused concurrent reductions in caveolin-1, p 53, p 21, and senescence-associated beta-galactosidase in the bone of rats and osteoblasts cultured with the serum of treated rats (39), thus, preventing senescence of osteoblasts. These are translated to a beneficial effect on the bone.

Overall, soy isoflavones modulate a complex network of factors influencing bone health. The net effects seem to be beneficial, considering the phenotypic response of the skeletal system on soy isoflavone supplementation. The mechanisms of action of soy isoflavones and soy protein isolates are summarized in Figure 2.

\section{CONCLUSION}

Early-life exposure to isoflavones, especially during the neonatal period, enhances BMD, skeletal microstructure, and strength in adulthood. Similarly, prepubertal or life-long supplementation suggested beneficial skeletal effects, which may reduce the skeletal negative effects of castration at adulthood. On the other hand, the prenatal plus postnatal exposure models reveal the negative effects of isoflavones. Further, basic research on the influence of isoflavones on the epigenetic process in embryos would explain the skeletal phenotypes observed. Mechanistically, the skeletal protection may be due to their direct actions on bone cells favoring osteogenesis and DNA methylation. The effects of isoflavones on TH homeostasis could bring more harm than benefits to the skeleton at this life stage. Therefore, soy infant formulation should not be initiated without proper evaluation of the risk and benefits. The evidence presented in this review should also be interpreted together with evidence from other organ systems, especially sex hormone-sensitive organs to assess the impacts of early-life exposure of isoflavones on developmental health holistically.

\section{AUTHOR CONTRIBUTIONS}

$\mathrm{K}-\mathrm{YC}$ and K-LP conceived the review. K-YC performed the literature search and drafted the manuscript. K-LP validated the search results and reviewed the manuscript. All authors contributed to the article and approved the submitted version. 


\section{FUNDING}

The researchers are funded by the Fundamental Research Grant Scheme (FRGS/1/2018/SKK10/UKM/03/1) provided by

\section{REFERENCES}

1. Goudochnikov VI. Role of hormones in perinatal and early postnatal development: Possible contribution to programming/imprinting phenomena. Russ J Dev Biol. (2015) 46:237-45. doi: 10.1134/S1062360415050045

2. Saccone G, Berghella V. Antenatal corticosteroids for maturity of term or near term fetuses: systematic review and meta-analysis of randomized controlled trials. BMJ. (2016) 355:i5044. doi: 10.1136/bmj.i5044

3. Jobe AH, Goldenberg RL. Antenatal corticosteroids: an assessment of anticipated benefits and potential risks. Am J Obstet Gynecol. (2018) 219:6274. doi: 10.1016/j.ajog.2018.04.007

4. Kuo AH, Li J, Li C, Huber HF, Schwab M, Nathanielsz PW, et al. Prenatal steroid administration leads to adult pericardial and hepatic steatosis in male baboons. Int J Obes (Lond). (2017) 41:1299-302. doi: 10.1038/ijo.2017.82

5. Zhu Z, Cao F, Li $\mathrm{X}$. Epigenetic programming and fetal metabolic programming. Front Endocrinol. (2019) 10:764. doi: 10.3389/fendo.2019.00764

6. Connelly KJ, Larson EA, Marks DL, Klein RF. Neonatal estrogen exposure results in biphasic age-dependent effects on the skeletal development of male mice. Endocrinology. (2015) 156:193-202. doi: 10.1210/en. 2014-1324

7. Lind T, Lejonklou MH, Dunder L, Kushnir MM, Ohman-Magi C, Larsson S, et al. Developmental low-dose exposure to bisphenol A induces chronic inflammation, bone marrow fibrosis and reduces bone stiffness in female rat offspring only. Environ Res. (2019) 177:108584. doi: 10.1016/j.envres.2019.108584

8. Chin KY, Ima-Nirwana S. Can soy prevent male osteoporosis? A review of the current evidence. Curr Drug Targets. (2013) 14:163241. doi: $10.2174 / 1389450114666131216222612$

9. Westmark CJ. Soy-based therapeutic baby formulas: testable hypotheses regarding the pros and cons. Front Nutr. (2017) 3:59. doi: $10.3389 /$ fnut.2016.00059

10. Franke AA, Halm BM, Custer LJ, Tatsumura Y, Hebshi S. Isoflavones in breastfed infants after mothers consume soy. Am J Clin Nutr. (2006) 84:40613. doi: $10.1093 / \mathrm{ajcn} / 84.2 .406$

11. Setchell KD, Zimmer-Nechemias L, Cai J, Heubi JE. Exposure of infants to phyto-oestrogens from soy-based infant formula. Lancet (London, England). (1997) 350:23-7. doi: 10.1016/S0140-6736(96)09480-9

12. Bhatia J, Greer F. Use of soy protein-based formulas in infant feeding. Pediatrics. (2008) 121:1062-8. doi: 10.1542/peds.2008-0564

13. Rossen LM, Simon AE, Herrick KA. Types of infant formulas consumed in the United States. Clin Pediatr (Phila). (2016) 55:278-85. doi: 10.1177/0009922815591881

14. Canadian Paediatric Society. Concerns for the use of soy-based formulas in infant nutrition. Paediatr Child Health. (2009) 14:109-18. doi: 10.1093/pch/14.2.109

15. Mcclain RM, Keller D, Casciano D, Fu P, Macdonald J, Popp J, et al. Neonatal mouse model: review of methods and results. Toxicol Pathol. (2001) 29 (Suppl.):128-137. doi: 10.1080/019262301753178537

16. Puiman P, Stoll B. Animal models to study neonatal nutrition in humans. Curr Opin Clin Nutr Metab Care. (2008) 11:6016. doi: 10.1097/MCO.0b013e32830b5b15

17. Dye JA, Gibbs-Flournoy EA, Richards JH, Norwood J, Kraft K, Hatch GE. Neonatal rat age, sex and strain modify acute antioxidant response to ozone. Inhal Toxicol. (2017) 29:291-303. doi: 10.1080/08958378.2017.1369602

18. Nikov GN, Hopkins NE, Boue S, Alworth WL. Interactions of dietary estrogens with human estrogen receptors and the effect on estrogen receptorestrogen response element complex formation. Environ Health Perspect. (2000) 108:867-72. doi: 10.1289/ehp.00108867 the Ministry of Education, Malaysia. K-LP is a postdoctoral research fellow funded by Universiti Kebangsaan Malaysia through Postdoctoral Research Scheme Modal Insan Penyelidikan (RGA1).

19. Kaludjerovic J, Ward WE. Neonatal exposure to daidzein, genistein, or the combination modulates bone development in female CD-1 mice. J Nutr. (2009) 139:467-73. doi: 10.3945/jn.108.100115

20. Kaludjerovic J, Ward WE. Adequate but not supplemental folic acid combined with soy isoflavones during early life improves bone health at adulthood in male mice. J Nutr Biochem. (2013) 24:1691-6. doi: 10.1016/j.jnutbio.2013.02.008

21. Kaludjerovic J, Ward WE. Bone-specific gene expression patterns and whole bone tissue of female mice are programmed by early life exposure to soy isoflavones and folic acid. J Nutr Biochem. (2015) 26:106876. doi: 10.1016/j.jnutbio.2015.04.013

22. Hertrampf T, Ledwig C, Kulling S, Molzberger A, Möller FJ, Zierau $\mathrm{O}$, et al. Responses of estrogen sensitive tissues in female Wistar rats to pre- and postnatal isoflavone exposure. Toxicol Lett. (2009) 191:1818. doi: 10.1016/j.toxlet.2009.08.019

23. Tousen $Y$, Ishiwata H, Takeda K, Ishimi $Y$. Assessment of safety and efficacy of perinatal or peripubertal exposure to daidzein on bone development in rats. Toxicol Rep. (2015) 2:429-36. doi: 10.1016/j.toxrep.2014.12.012

24. Atkinson C, Frankenfeld CL, Lampe JW. Gut bacterial metabolism of the soy isoflavone daidzein: exploring the relevance to human health. Exp Biol Med (Maywood). (2005) 230:155-70. doi: 10.1177/153537020523000302

25. Kaludjerovic J, Ward WE. Neonatal administration of isoflavones attenuates deterioration of bone tissue in female but not male mice. J Nutr. (2010) 140:766-72. doi: 10.3945/jn.109.116343

26. Chin KY, Ima-Nirwana S. The biological effects of tocotrienol on bone: a review on evidence from rodent models. Drug Des Devel Ther. (2015) 9:2049-61. doi: 10.2147/DDDT.S79660

27. Camacho L, Lewis SM, Vanlandingham MM, Juliar BE, Olson GR, Patton $\mathrm{RE}$, et al. Comparison of endpoints relevant to toxicity assessments in three generations of CD-1 mice fed irradiated natural and purified ingredient diets with varying soy protein and isoflavone contents. Food Chem Toxicol. (2016) 94:39-56. doi: 10.1016/j.fct.2016.05.014

28. Piekarz AV, Ward WE. Effect of neonatal exposure to genistein on bone metabolism in mice at adulthood. Pediatr Res. (2007) 61:4853. doi: 10.1203/01.pdr.0000250200.94611.03

29. Kim HS, Jeong ES, Yang MH, Yang SO. Bone mineral density assessment for research purpose using dual energy X-ray absorptiometry. Osteoporos Sarcopenia. (2018) 4:79-85. doi: 10.1016/j.afos.2018.09.003

30. Chin KY, Ima-Nirwana S. Sex steroids and bone health status in men. Int $J$ Endocrinol. (2012) 2012:208719. doi: 10.1155/2012/208719

31. Mohamad NV, Soelaiman IN, Chin KY. A concise review of testosterone and bone health. Clin Interv Aging. (2016) 11:1317-24. doi: 10.2147/CIA.S115472

32. Campbell GM, Sophocleous A. Quantitative analysis of bone and soft tissue by micro-computed tomography: applications to ex vivo and in vivo studies. Bonekey Rep. (2014) 3:564. doi: 10.1038/bonekey.2014.59

33. Cole JH, Van Der Meulen MCH. Whole bone mechanics and bone quality. Clin Orthop Relat Res. (2011) 469:2139-49. doi: 10.1007/s11999-011-1784-3

34. Siddiqui JA, Partridge NC. Physiological bone remodeling: systemic regulation and growth factor involvement. Physiology (Bethesda, Md). (2016) 31:233-45. doi: 10.1152/physiol.00061.2014

35. Shetty S, Kapoor N, Bondu JD, Thomas N, Paul TV. Bone turnover markers: emerging tool in the management of osteoporosis. Indian J Endocrinol Metab. (2016) 20:846-52. doi: 10.4103/2230-8210.192914

36. Boyce BF, Xing L. Biology of RANK, RANKL, and osteoprotegerin. Arthritis Res Ther. (2007) 9(Suppl. 1):S1. doi: 10.1186/ar2165

37. Sato N, Yamakawa N, Masuda M, Sudo K, Hatada I, Muramatsu M. Genome-wide DNA methylation analysis reveals phytoestrogen modification of promoter methylation patterns during embryonic stem cell differentiation. PLoS ONE. (2011) 6:e19278. doi: 10.1371/journal.pone.0019278 
38. Zhang J, Lazarenko OP, Wu X, Tong Y, Blackburn ML, Gomez-Acevedo H, et al. Differential effects of short term feeding of a soy protein isolate diet and estrogen treatment on bone in the prepubertal rat. PLoS ONE. (2012) 7:e35736. doi: 10.1371/journal.pone.0035736

39. Chen J-R, Lazarenko OP, Blackburn ML, Shankar K. Dietary factors during early life program bone formation in female rats. FASEB J. (2017) 31:37687. doi: 10.1096/fj.201600703r

40. Hotchkiss CE, Weis C, Blaydes B, Newbold R, Delclos KB. Multigenerational exposure to genistein does not increase bone mineral density in rats. Bone. (2005) 37:720-7. doi: 10.1016/j.bone.2005.06.005

41. Sliwiński L, Folwarczna J, Janiec W, Grynkiewicz G, Kuzyk K. Differential effects of genistein, estradiol and raloxifene on rat osteoclasts in vitro. Pharmacol Rep. (2005) 57:352-9.

42. Cepeda SB, Sandoval MJ, Crescitelli MC, Rauschemberger MB, Massheimer VL. The isoflavone genistein enhances osteoblastogenesis: signaling pathways involved. J Physiol Biochem. (2020) 76:99110. doi: 10.1007/s13105-019-00722-3

43. Kim M, Lim J, Lee JH, Lee KM, Kim S, Park KW, et al. Understanding the functional role of genistein in the bone differentiation in mouse osteoblastic cell line MC3T3-E1 by RNA-seq analysis. Sci Rep. (2018) 8:3257. doi: 10.1038/s41598-018-21601-9

44. Yu B, Tang DZ, Li SY, Wu Y, Chen M. Daidzein promotes proliferation and differentiation in osteoblastic OCT1 cells via activation of the BMP-2/Smads pathway. Pharmazie. (2017) 72:35-40. doi: 10.1691/ph.2017.6502

45. Jin X, Sun J, Yu B, Wang Y, Sun WJ, Yang J, et al. Daidzein stimulates osteogenesis facilitating proliferation, differentiation, and antiapoptosis in human osteoblast-like MG-63 cells via estrogen receptor-dependent MEK/ERK and PI3K/Akt activation. Nutr Res. (2017) 42:20-30. doi: 10.1016/j.nutres.2017.04.009

46. Sun J, Sun WJ, Li ZY, Li L, Wang Y, Zhao Y, et al. Daidzein increases OPG/RANKL ratio and suppresses IL-6 in MG-63 osteoblast cells. Int Immunopharmacol. (2016) 40:32-40. doi: 10.1016/j.intimp.2016.08.014

47. Ohtomo T, Uehara M, Peñalvo JL, Adlercreutz H, Katsumata S, Suzuki $\mathrm{K}$, et al. Comparative activities of daidzein metabolites, equol and Odesmethylangolensin, on bone mineral density and lipid metabolism in ovariectomized mice and in osteoclast cell cultures. Eur J Nutr. (2008) 47:2739. doi: 10.1007/s00394-008-0723-x

48. Wang J, Xu J, Wang B, Shu FR, Chen K, Mi MT. Equol promotes rat osteoblast proliferation and differentiation through activating estrogen receptor. Genet Mol Res. (2014) 13:5055-63. doi: 10.4238/2014.July.4.21

49. Ghayor C, Weber FE. Epigenetic regulation of bone remodeling and its impacts in osteoporosis. Int $J$ Mol Sci. (2016) 17:1446. doi: 10.3390/ijms17091446

50. Cho YD, Yoon WJ, Kim WJ, Woo KM, Baek JH, Lee G, et al. Epigenetic modifications and canonical wingless/int-1 class (WNT) signaling enable trans-differentiation of nonosteogenic cells into osteoblasts. J Biol Chem. (2014) 289:20120-8. doi: 10.1074/jbc.M114.558064

51. Ivashkiv LB. Metabolic-epigenetic coupling in osteoclast differentiation. Nat Med. (2015) 21:212-3. doi: 10.1038/nm.3815

52. Wang W, Sun Y, Guo Y, Cai P, Li Y, Liu J, et al. Continuous soy isoflavones exposure from weaning to maturity induces downregulation of ovarian steroidogenic factor 1 gene expression and corresponding changes in DNA methylation pattern. Toxicol Lett. (2017) 281:17583. doi: 10.1016/j.toxlet.2017.09.021

53. Pistollato F, Masias M, Agudo P, Giampieri F, Battino M. Effects of phytochemicals on thyroid function and their possible role in thyroid disease. Ann N Y Acad Sci. (2019) 1443:3-19. doi: 10.1111/nyas.13980
54. Bassett JHD, Williams GR. Role of thyroid hormones in skeletal development and bone maintenance. Endocr Rev. (2016) 37:135-87. doi: 10.1210/er.2015-1106

55. Chin K-Y, Ima-Nirwana S, Mohamed IN, Aminuddin A, Johari MH, Ngah WZW. Thyroid-stimulating hormone is significantly associated with bone health status in men. Int J Med Sci. (2013) 10:857-63. doi: 10.7150/ijms.5870

56. Tuchendler D, Bolanowski M. The influence of thyroid dysfunction on bone metabolism. Thyroid Res. (2014) 7:12-12. doi: 10.1186/s13044-014-0012-0

57. Tonstad S, Jaceldo-Siegl K, Messina M, Haddad E, Fraser GE. The association between soya consumption and serum thyroid-stimulating hormone concentrations in the Adventist Health Study-2. Public Health Nutr. (2016) 19:1464-70. doi: 10.1017/S1368980015002943

58. Janulewicz PA, Carlson JM, Wesselink AK, Wise LA, Hatch EE, Edwards $\mathrm{LM}$, et al. Urinary isoflavones levels in relation to serum thyroid hormone concentrations in female male adults in the U.S. general population. Int J Environ Health Res. (2019) 6:1-12. doi: 10.1080/09603123.2019.1663497

59. Doerge DR, Sheehan DM. Goitrogenic and estrogenic activity of soy isoflavones. Environ Health Perspect. (2002) 110(Suppl. 3):349-53. doi: 10.1289/ehp.02110s3349

60. Radović B, Mentrup B, Köhrle J. Genistein other soya isoflavones are potent ligands for transthyretin in serum cerebrospinal fluid. Br J Nutr. (2006) 95:1171-6. doi: 10.1079/BJN20061779

61. Šošić-Jurjević B, Ajdžanović V, Filipović B, Severs W, Milošević V. Thyroid mediation of the isoflavone effects on osteoporotic bone: the endocrine interference with a beneficial outcome. Front. Endocrinol. (2019) 10:688. doi: 10.3389/fendo.2019.00688

62. Renko K, Schäche S, Hoefig CS, Welsink T, Schwiebert C, Braun D, et al. An improved nonradioactive screening method identifies genistein and xanthohumol as potent inhibitors of iodothyronine deiodinases. Thyroid. (2015) 25:962-8. doi: 10.1089/thy.2015.0058

63. Williams AJ, Robson H, Kester MHA, Van Leeuwen JPTM, Shalet SM, Visser TJ, et al. Iodothyronine deiodinase enzyme activities in bone. Bone. (2008) 43:126-34. doi: 10.1016/j.bone.2008.03.019

64. Ariyani W, Iwasaki T, Miyazaki W, Yu L, Takeda S, Koibuchi N. A possible novel mechanism of action of genistein and daidzein for activating thyroid hormone receptor-mediated transcription. Toxicol Sci. (2018) 164:41727. doi: 10.1093/toxsci/kfy097

65. Swart AC, Johannes ID, Sathyapalan T, Atkin SL. The effect of soy isoflavones on steroid metabolism. Front Endocrinol. (2019) 10:229. doi: 10.3389/fendo.2019.00229

66. Refetoff S. Thyroid hormone serum transport proteins. In: Feingold KR, Anawalt B, Boyce A, Chrousos G, Dungan K, Grossman A, editors. Endotext. South Dartmouth, MA: MDText.com, Inc. (2000).

67. Palha JA, Episkopou V, Maeda S, Shimada K, Gottesman ME, Saraiva MJ. Thyroid hormone metabolism in a transthyretin-null mouse strain. J Biol Chem. (1994) 269:33135-9.

Conflict of Interest: The authors declare that the research was conducted in the absence of any commercial or financial relationships that could be construed as a potential conflict of interest.

Copyright $(2020$ Chin and Pang. This is an open-access article distributed under the terms of the Creative Commons Attribution License (CC BY). The use, distribution or reproduction in other forums is permitted, provided the original author(s) and the copyright owner(s) are credited and that the original publication in this journal is cited, in accordance with accepted academic practice. No use, distribution or reproduction is permitted which does not comply with these terms. 